This item was submitted to Loughborough's Research Repository by the author.

Items in Figshare are protected by copyright, with all rights reserved, unless otherwise indicated.

\title{
Cash holdings of listed and unlisted firms: new evidence from the euro area
}

PLEASE CITE THE PUBLISHED VERSION

PUBLISHER

Taylor \& Francis (Routledge)

VERSION

AM (Accepted Manuscript)

PUBLISHER STATEMENT

This is an Accepted Manuscript of an article published by Taylor \& Francis in The European Journal of Finance on 12 August 2019, available online: http://www.tandfonline.com/10.1080/1351847X.2019.1652197.

\section{LICENCE}

CC BY-NC-ND 4.0

\section{REPOSITORY RECORD}

Asimakopoulos, Panagiotis, Stylianos Asimakopoulos, and Filipa Da Silva Fernandes. 2019. "Cash Holdings of Listed and Unlisted Firms: New Evidence from the Euro Area". figshare.

https://hdl.handle.net/2134/9808382.v1. 


\title{
Cash holdings of listed and unlisted firms: New evidence from the euro area
}

\author{
Panagiotis Asimakopoulos, Stylianos Asimakopoulos`, Filipa Da Silva Fernandes ${ }^{\ddagger}$
}

\begin{abstract}
This paper examines the cash holdings behavior of listed and unlisted firms. We argue that unlisted firms, which are smaller, face a greater wedge between the cost of external and internal finance and as a result they need to rely more on the later. Relying on internal funds means that firms have a precautionary motive to hold cash. We test our theory using an unbalanced panel of mainly small medium enterprises within the euro area over the period 2003-2017 paying special attention to the role of financial pressure, financial constraints and the recent financial crisis. Our findings reveal that unlisted firms hold more cash than their listed counterparts due to precautionary motives. In addition, when considering the effect of financial pressure, the results show that the difference in cash holdings between listed and unlisted firms exhibit a "Ushaped" relationship. Finally, unlisted firms have a higher sensitivity to save cash out of cash flow than listed firms. Our results are robust to using different specifications and different financial pressure measures.
\end{abstract}

Keywords: cash holdings, listed and unlisted firms, precautionary motives, financial pressure JEL Classification: C23, C26, G01, G30, G32

${ }^{*}$ Corresponding author, Loughborough University, School of Business and Economics; Email: p.asimakopoulos@lboro.ac.uk

${ }^{\dagger}$ University of Bath, Department of Economics; Email: s.asimakopoulos@bath.ac.uk

${ }^{\ddagger}$ University of Aberdeen, Business School; Email: filipaalexandra.dasilvafernandes@abdn.ac.uk 


\section{Introduction}

Firms' cash holdings policies have been the focal point for financial economists the last decades due to the complex and competitive financial settings. Based on the seminal work of Opler et al. (1999), firms' financial policies ${ }^{1}$ have a significant role in corporate cash management policies. The primary aim of this study is to assess the differences in the behavior of cash holdings between unlisted and listed firms. Our findings indicate that: i) the precautionary saving motive can impact firm cash holdings and leads to unlisted firms holding more cash compared to the listed firms and ii) the sensitivity of cash to cash flow is higher in unlisted firms so as to react promptly to unforeseen changes in their cash flow pattern or investment opportunity set.

The key question in the related literature is: Does it pay for unlisted firms to become listed with regard to their cash reserves policies? Listed firms may acquire additional capital at a lower cost, avoid the costs of raising external funds or liquidating existing assets compared to unlisted firms. This way listed firms can undertake growth opportunities which they otherwise would have to forgo, especially if they were financially constraint. Moreover, listed firms may have reduced asymmetric information, monitoring and contracting costs enhancing the net present value of their investment policies.2 ${ }^{2}$ Mortal and Reisel (2013) point out that listed firms may allocate capital more efficiently and their investment sensitivity to growth opportunities is higher than unlisted counterparts. Contrary to the positive consequences of being listed, both the agency cost associated with the ownership dispersion and the costs of losing control in decision-making may outweigh the potential benefits.

Therefore, there is no obvious answer on whether a firm should be listed or not. The implied trade-off between listed and unlisted firms affects their cash management policy. This situation is even more puzzling once we take into account that firms are traded under

\footnotetext{
${ }^{1}$ Such as dividend payout, cash flow management, working capital, and investment plans.

${ }^{2}$ See Chen et al. (2007) and Edmans et al. (2012) for empirical evidence.
} 
imperfect capital markets and operate with various frictions and financial flexibility issues. The latter is an important consideration in many capital structure decisions. Managers must ensure that they retain sufficient financial resources within the firm so as to take advantage of unanticipated investment opportunities and to overcome unforeseen problems. Yet, listed and unlisted firms have different degrees of financial flexibility as the later face more financial frictions than listed firms(Saunders and Steffen, 2011).

Hence, it is crucial not only to examine the cash reserve policies, especially for vulnerable firms such as the Small and Medium Enterprises (SMEs), but also to investigate how potential turbulence in the financial markets and in real economy could affect these policies. For example, Almeida et al. (2017) argue that firms' sovereign-driven downgrades affect their cash holding behavior through the use of their cash reserves to either mitigate the negative financial shock or regain their pre-downgrade credit rating or even for precautionary reasons.

Our paper examines the cash holdings behavior of listed and unlisted firms using a comprehensive dataset of European firms, most of which are SMEs ${ }^{3}$ Within the euro area (EA), SMEs are the workhorse of the economy, being responsible for about $60 \%$ of production (Muller et al., 2016). Figure 1 shows the evolution of average cash holdings of Euro area (EA) firms. In the early 2000s, the invention of mortgage-backed securities (MBS) completely transformed the housing, banking and mortgage businesses. Until 2007, firms held low cash reserves because loans were relatively easy to obtain and credit spreads were low. This led to the well-known housing bubble that burst in 2007 reducing significantly the supply of bank loans. As a result, firms had to search for alternative sources of financing suffering from liquidity problems, while credit spreads had radically increased. The precautionary demand for cash reserves during increased and firms started to hold excess cash ensuring that they

\footnotetext{
${ }^{3}$ The unlisted firm classification includes both private firms and unlisted public firms. The listed firm classification includes all type of listed firms. So, the term "listed" is similar to the term "public" as used in literature. The separation between unlisted and listed firms is crucial and in this paper we follow the work of Mortal and Reisel (2013). For each firm into investigation its Initial Public Offering (IPO) date and delisting date from the stock market is checked. Then firms are reclassified as unlisted or listed based on this information. See more details in Section 3.
} 
will be able to keep their investment opportunities.4 After 2010 cash reserves stabilized due to the decline of interest rates from the European Central Bank (ECB). However, cash holdings increased again when the interest rate reached the zero lower bound and uncertainty increased regarding the stability of the eurozone. Therefore, Figure 1 illustrates that cash holding behavior of EA firms fluctuate over time mainly due to market frictions.

The idea that market frictions play an important role in firms' decisions to hold cash is an old one (Miller and Orr, 1966; Kim et al., 1998). The amount of cash reserves that will be held by a firm, after distributing the appropriate dividend to its shareholders and investing the remaining amount in physical or financial investments, is correlated to its investment opportunity set which, in turn, depend on financial flexibility. However, firm's reaction to an unforeseen change in the firm's cash flow pattern or investment opportunities set depends on the availability of precautionary funds, the access to external funds and the cost of external financing. Thus, in the presence of market frictions, a firm's financing decisions are related to its investment decisions.

Following Keynes (1936) that cash holdings may be beneficial to firms with limited access to external capital markets, many studies have been emerged proposing three key theoretical justifications of why firms alter their cash reserves. These are the trade-off theory, the pecking order theory and the free cash flow theory.

The trade-off theory points out that firms ascertain their optimal level of cash holdings by weighting the marginal costs and benefits. The costs are due to the opportunity cost of the capital invested in liquid assets, while the benefits steam from transaction and precautionary motives 5

The pecking order theory, introduced by Myers (1984) and Myers and Majluf (1984), states that firms use cash as a buffer between retained earnings and investment needs, instead

\footnotetext{
${ }^{4}$ Chava and Purnanandam (2011) find that bank-dependent firms are more affected during banking crises than firms with access to public debt markets. Carvalho et al. (2015) find that borrowers with pre-crisis relationships with less healthy lenders were more affected by the 2007-2009 financial crisis compared to borrowers of healthier lenders.

${ }^{5}$ For empirical support of trade-off theory see Opler et al. (1999), Almeida et al. (2004), Ozkan and Ozkan (2004), Han and Qiu (2007) and Bates et al. (2009), among others.
} 
of defining a target cash level..$^{6}$ Regarding the free cash flow theory, Jensen (1986) argues that managers have an incentive to accumulate cash reserves rather than pay them out to shareholders, generating agency concerns and increasing the information asymmetry.7

Many empirical studies have tried to verify the above theoretical explanations without any clear agreement. The majority of them is focused on cash holdings by listed firms in the U.S. market, due to lack of available data for unlisted firms (Kim et al., 1998; Opler et al., 1999; Almeida et al., 2004; Harford et al., 2008; Bates et al., 2009). Other studies examined cash holdings behavior incorporating the effectiveness of country's legal and financial institutions, as well as the importance of other country-level determinants of cash, focusing again on listed firms (Pinkowitz and Williamson, 2001; Ozkan and Ozkan, 2004; Ferreira and Vilela, 2004; Pinkowitz et al., 2006; Kalcheva and Lins, 2007; Iskandar-Datta and Jia, 2012). For example, Chen et al. (2012), using Chinese firms. ${ }^{8}$ examine the level of cash holdings and/or the cash to cash flow sensitivities, whereas Guariglia and Yang (2016a) investigate the existence of a target level of cash holdings. These papers focus, once more, on listed companies.

Therefore, unlisted firms have not received the required attention in the related literature. Gao et al. (2013), an exemption to this statement, using a sample of large U.S. firms, find that unlisted companies hold less cash than the listed ones despite higher financing frictions and they point out that agency costs add substantially to a firm's cash holdings.

Most of the aforementioned studies articulate a puzzling and controversial argument, that listed firms hold more cash than their unlisted counterparts due to agency motives. However, the traditional literature on cash holdings suggests that unlisted firms are considered to suffer from higher levels of information asymmetry and higher transaction costs and so they hoard more cash for precautionary reasons (Keynes, 1936; Baumol, 1952; Miller and Orr, 1966). Critical is also the fact that these studies remain silent regarding differences in cash holdings

\footnotetext{
${ }^{6}$ For empirical support of pecking order theory see de Haan and Hinloopen (2003), Dittmar et al. (2003), Ferreira and Vilela (2004) and Bigelli and Sánchez-Vidal (2012).

${ }^{\top}$ For empirical support of free cash-flow theory see Harford (1999), Dittmar and Mahrt-Smith (2007) and Kalcheva and Lins (2007).

${ }^{8}$ China has a unique environment due to lage share of government ownership of the firms.
} 
when considering samples with a large share of Small and Medium Enterprises (SMEs). This is more interesting if we take into account the fact that liquidity constraints are higher for smaller firms, especially SMEs (Belghitar and Khan, 2013; Vermoesen et al., 2013).9

As a consequence, the primary aim of this study is to fill this gap in the existing literature and to assess the differences in the behavior of cash holdings between unlisted and listed firms by employing a large sample of SMEs in the EA 10 To the best of our knowledge, our work is the first to exploit an extensive sample of 10 EA countries ${ }^{11}$ for the period 2003-2017. In our study we are able to assess not only whether unlisted firms hold higher cash reserves than their listed counterparts in a cross-country analysis, but also to investigate whether the recent global financial crisis altered the cash holding behavior affecting as a consequence their investment financing and payout policies ${ }^{12}$

Our research also contributes to the stream of literature that assesses the role of financial pressure on unlisted and listed firms' cash holdings decisions. Acharya et al. (2012) are among the first who attempted to identify a link between financial pressure and cash holdings. The authors argued that U.S. firms with higher levels of financial pressure hold more cash as a buffer. In addition, Benito and Young (2007) and Guariglia and Yang (2016b) show that financial pressure in the form of debt-servicing costs has a negative effect on firms' employment and investment decisions. In our work we use two different proxies of financial pressure(Benito and Young, 2007; Guariglia and Yang, 2016b) to assess whether changes in the impact of financial pressure affect differently cash holdings of unlisted and listed firms. We also test how that impact changes when heterogeneous interest payment obligations are taken into account.

\footnotetext{
${ }^{9}$ Furthermore, SMEs have more difficulties in raising finance compared to large firms and normally encounter difficulties in signaling their creditworthiness (De Maeseneire and Claeys (2012)).

${ }_{10}$ Gao et al. (2013) and Farre-Mensa (2014) employ a sample of firms from Capital IQ database. This database only reports information on private and public firms with minimum annual revenue of approximately 5 million euros. Amadeus, which is the database used in this paper, includes information on firms with less than 2 million euros.

${ }^{11}$ Austria, Belgium, Finland, France, Germany, Greece, Italy, Luxembourg, Portugal and Spain.

${ }^{12}$ There is another strand of literature assessing temporary and permanent cash flow shocks and their impact on cash holdings, e.g. Gryglewicz et al. (2017). However, our paper is deviating from these papers as our variable of interest utilizes a permanent firm status rather than a shock.
} 
This paper also explores the sensitivity of unlisted and listed firms to cash flow. Firms hold cash to protect themselves against the adverse cash flow shocks that might force them to miss investment opportunities due to costly external finance (Bates et al., 2009; Gao et al., 2013). ${ }^{13}$ Information asymmetry is another important factor that may alter the cash holdings behavior of unlisted versus listed firms. ${ }^{14}$ When unlisted firms need cash to finance unforeseen investment opportunities or to face a financing deficit, according to the pecking order theory, they must issue debt. Therefore, due to financial constraints and information asymmetry $\sqrt[15]{15}$ unlisted firms may have greater precautionary demand for cash than listed, but concurrently unlisted firms may have fewer agency conflicts (Brau and Fawcett, 2006), which leads to fewer cash holdings.

These findings indicate an obvious trade-off between agency costs and precautionary motives on cash holdings behavior between listed and unlisted firms. For example, if the precautionary demand dominates the agency costs for the unlisted firms, then these firms should exhibit higher cash holdings than listed firms.

Our results show that unlisted firms hold more cash than their listed counterparts due to precautionary motives. This is due to the fact that unlisted firms in the Euro-area are by definition smaller in size and suffer from higher levels of liquidity constraints than the listed ones ${ }^{16}$ These results contradict the empirical literature on the unlisted-listed cash holdings nexus but are in line with the earlier studies on cash reserves. When considering the effect of financial pressure on firms' cash holdings decisions, our results show that the

\footnotetext{
${ }^{13}$ Denis (2011) claims that firms with costly external financing can undertake valuable investments opportunities only by keeping larger cash reserves.

${ }^{14}$ Information asymmetry is considered as an important barrier for unlisted firms, as they are subject to lower levels of disclosure, supervision and external auditing. Additionally, unlisted firms lack a public price as a mechanism to signal their quality to investors, they do not benefit from the presence of analysts and they are subject to less accurate and less efficient monitoring (Mantecon, 2008).

15 Asimakopoulos et al. (2017) show that under asymmetric information investors by using an appropriate econometric technique that utilize a time-disaggregated dividend-price ratio could reveal the link between dividend yield and future dividend growth, exploiting on that way good listed-firm prospects which are embedded in the stock price while dividends are sticky or smoothed. Also, Brav (2009) points out that public firms are reluctant to alter their dividend policy in response to changes in their performance, contrary to what happens in private firms which are more sensitive to their operating performance.

${ }^{16}$ This argument is supported by recent studies which explore firm behavior in the Euro-area (see for example Ferrando and Mulier (2013).
} 
cash holding differential between unlisted and listed firms exhibit a U-shape as the relative difference decreases for an average level of financial pressure. In addition, the difference is more pronounced at the lower level of financial pressure compared to the highest level. This is a novel result extending the work of Acharya et al. (2012) who show that there is a U-shaped relationship between cash holdings of public U.S. firms and credit risk 17

Finally, cash flow sensitivity of cash is higher for unlisted firms compared to listed. This result denotes that unlisted firms have a larger need for cash holdings as cash reserves are more useful in helping to avoid adverse shocks to cash flows. In addition, the same pattern is observed when we take into account the financial crisis. We also show that despite the evidence that the effect of agency conflicts is important for unlisted firms, financing frictions are strong enough to lead to higher cash holdings in unlisted firms. Overall, our results support the precautionary motive to hold cash contributing to the extensive literature by providing new evidence on how capital market imperfections affect the levels of cash holdings of unlisted firms 18

The remainder of the paper is structured as follows: In section 2 we explain and motivate our methodology. In Section 3 we analyze the data-set. Section 4 presents the empirical results. Section 5 provides several robustness checks, while section 6 concludes the paper and provides policy implications.

\section{Econometric specification and methodology}

\subsection{Cash holdings of listed and unlisted firms}

Following the related literature (Opler et al., 1999; Gao et al., 2013), this paper uses a static model of cash holdings to examine differences between listed and unlisted firms cash

\footnotetext{
${ }^{17}$ Riskier firms hold higher levels of cash as a precaution since they have higher levels of debt relative to their cash flows. Low-risk firms also hold higher levels of cash due to a pecking order issue.

${ }^{18}$ Our results remain unchanged when we use the propensity score matching approach for the unlisted firms so as to match the listed firms sample to deal with the fact that the majority of our sample consists of unlisted firms.
} 
decisions. The equation has the following form:

$$
\begin{aligned}
\text { cash }_{i t}= & \alpha+\beta_{1} \text { Unlisted }_{t}+\beta_{2} \text { Size }_{i t}+\beta_{3} \text { CashFlow }_{i t}+\beta_{4} \text { Salesgr }_{i t} \\
& +\beta_{5} \text { Lever }_{i t}+\beta_{6} N W C_{i t}+\beta_{7} \text { Ln }(\text { age })_{i t}+\beta_{9} \text { CapExp }_{i t}+\beta_{10} \text { CasfFlow_vol }_{i t} \\
& +\beta_{11} \text { Cost of empl }_{i t}+\beta_{12} \text { Sharehold.Funds }_{i t}+\varepsilon_{i t}
\end{aligned}
$$

where $i=1,2, \ldots, N$ indicates firms and $t=1,2, \ldots, T$ indicates years. Cash $_{i t}$ is the natural logarithm of the cash ratio. Size $e_{i t}$ corresponds to the natural logarithm of total assets while CasFlow $_{i t}$ indicates the ratio of cash flow to total assets. CashFlow_vol ${ }_{i t}$ denotes the cash flow volatility which is measured as the standard deviation of industry-adjusted yearly cash flow over the previous three years. Salesgr ${ }_{i t}$ corresponds to the growth rate of sales. Lever $_{i t}$ indicates leverage defined as total debt scaled by total assets. $N W C_{i t}$ indicates net working capital measured as the difference between current assets and current liabilities excluding cash scaled by total assets. $\operatorname{Ln}(\text { age })_{i t}$ corresponds to the natural logarithm of firms' age which is calculated as the difference between the present year and firms' date of


plus depreciation divided by total assets. Finally, Cost of empl.it denotes the total personnel expense, while Sharehold.Funds $s_{i t}$ captures total shareholders funds and liabilities. Values are in 2005 prices, using the Consumer Price Index (CPI).$^{19}{ }^{20}$

Unlisted $_{t}$ is the key explanatory variable for the analysis and it accounts for the percentage of cash holdings for unlisted firms compared to their listed counterparts. This variable is measured as a dummy variable (Gao et al., 2013). It takes the value of one if the firms are not listed and zero otherwise. Different from previous studies on listed and unlisted cash holdings (Gao et al., 2013), which have used databases where large firms prevail, our study

\footnotetext{
${ }^{19}$ To overcome the limited data availability of R\&D expenses we follow Brown and Petersen (2011) and Guney et al. (2017) and we use the cost of employees as a proxy for R\&D defined as the firms' total personnel. In addition, as in Bigelli and Sánchez-Vidal (2012) and Mulier et al. (2016), data on dividends are unavailable in Amadeus and as a result we are not able to use them in our analysis.

${ }^{20}$ See Table A1 in the Appendix for the definition of the variables in the data-set.
} 
uses a sample of mainly unquoted firms. ${ }^{21}$

The error term $\varepsilon_{i t}$ includes a firm-specific time-invariant component, including all timeinvariant firm characteristics likely to have an impact on the cash holdings variable and it also accounts for the time-invariant component of the measurement error affecting any of the regression variables: a time specific component accounting for possible business cycle effects and an idiosyncratic component. Finally, this paper controls for firm-specific time-invariant component of the error term by estimating the equation in first-differences and for the timespecific component by including time dummies (in addition to the time dummies interacted with industry dummies) in all specifications (see Brown et al. (2009)). Country dummies are also used to control for institutional differences between countries.

\section{$2.2 \quad$ Financial pressure}

This sub-section considers whether financial pressure has an impact on the relative cash holdings difference across the sample of listed and unlisted firms. This variable is measured as the ratio of cash flow to interest payments. This is thought to be an efficient measure of firms' level of creditworthiness (Acharya et al., 2012). The higher the level of creditworthiness, the better is the balance sheet of the firm. To test this hypothesis, firms are divided into deciles of financial pressure (coverage ratio). Keeping with the standard practice in the literature (Acharya et al., 2012), three different categories of financial pressure are considered: higher ( $1^{\text {st }}$ decile), medium ( $5^{\text {th }}$ decile) and lower $\left(10^{\text {th }}\right.$ decile $)$.

Following Acharya et al. (2012) rationale, firms which suffer from higher levels of financial pressure are more restricted in the access to external markets and therefore, they hold more cash as a precaution against a possible decrease of cash flows in the future. Nevertheless, if the differential between listed and unlisted firms' cash holdings in the lower group is also higher it indicates that unlisted firms hold more cash due to a pecking order issue. These firms suffer from higher levels of asymmetric information, and therefore, they prefer internal

\footnotetext{
${ }^{21}$ See sub-section 3.1 for details.
} 
finance over external holding cash as a buffer.

\subsection{Sensitivity of unlisted firms to cash flow}

Finally, this paper also considers if unlisted firms have a different propensity to save cash

out of cash flows. In particular, it is tested whether unlisted firms have a higher cash flow sensitivity of cash than their listed counterparts. Following Almeida et al. (2004), firms which face a higher degree of information asymmetry are less likely to access external capital markets, and therefore, have a tendency to save higher levels of their operating cash flow as cash.

To test the aforementioned assumption, equation (1) is re-formulated as in Almeida et al. (2004):

$$
\begin{aligned}
\text { sash }_{i t}= & \alpha+\beta_{1} \text { Unlisted }_{t}+\beta_{2} \text { Unlisted }_{t} * \text { CasFlow }_{i t}+\beta_{3} \text { Size }_{i t} \\
& +\beta_{4} \text { CasFlow }_{i t}+\beta_{5} \text { Salesgr }_{i t}+\beta_{6} \Delta N W C_{i t}+\beta_{7} \text { CapExp }_{i t} \\
& +\beta_{8} \Delta \text { STdebt }_{i t}+\beta_{9} \text { Cost of empl }_{i t}+\beta_{10} \text { Sharehold.Fund }_{i t}+\varepsilon_{i t}
\end{aligned}
$$

where, $\Delta$ cash $_{i t}$ represents the change in log of cash and equivalents to total assets. $\Delta N W C_{i t}$ denotes the change in net working capital, while $\Delta S T$ debt is the change in the ratio of shortterm debt.

\subsection{Econometric methodology}

All models are estimated in first-differences, to control for firm-specific, time-invariant effects. Given that most firm-specific variables in these models may suffer from endogeneity, this paper employ a system Generalized Method of Moments (GMM) approach (Arellano and Bover, 1995; Blundell and Bond, 1998). The estimator combines in a system the relevant equation in first differences and in levels. It makes use of the values of the regressors lagged twice or more as instruments in the differenced equation and of differences of the regressors 
lagged once in the levels equation. The system GMM reduces the finite sample bias and the root mean squared error (Blundell and Bond, 1998; Blundell et al., 2001). Year, country and industry dummies are also included in the regressions and instrument sets.

The validity of the GMM estimator depends on two different criteria. First, test for the existence of $n$ th-order serial correlation in the differenced of the residuals using the $\mathrm{m}(n)$ test, which is asymptotically distributed as a standard normal under the null of no serial correlation of the differenced residuals. Second, the Sargan test which is a test for overidentifying restrictions. Under the null of instrument validity, it is asymptotically distributed as a chi-square with degrees of freedom equal to the number of instruments less the number of parameters ${ }^{22}$

\section{Data}

\subsection{Data description}

To construct our dataset we use the annual accounting reports taken from AMADEUS (Analyse Major Database from European Sources), published by Bureau Van Dijk Electronic Publishing (BvDEP). The database comprises financial information on 19 million public and private firms across European countries. To construct our data set, we use three different versions of Amadeus. Specifically, we use AMADEUS November 2012, January 2017 and August 2018, to collect data for the period 2003-2017. This approach allows us to address the potential attrition bias as AMADEUS keeps only firms that have not been inactive for more than four years (Guariglia et al. 2015). The data-set includes the following ten euro area countries: Austria, Belgium, Finland, France, Germany, Greece, Italy, Luxembourg,

\footnotetext{
${ }^{22}$ It should be noted that the latter test can be relatively weak for large samples. Blundell et al. (2001) shows using Monte Carlo experiments that this test tends to over-reject the null hypothesis of valid instruments for the system GMM, especially for large samples. Chen and Guariglia (2013) confirm this result using a large panel of Chinese firms.
} 
Portugal and Spain ${ }^{23}{ }^{24}$

Following the literature on cash holdings (Gao et al., 2013, Farre-Mensa, 2014), this paper uses information on the legal form of the firms (i.e. listed and unlisted) ${ }^{25}$ We follow the work of Mortal and Reisel (2013) for the separation between listed and unlisted firms. Therefore, for each firm we check its Initial Public Offering (IPO) date and delisting date from the stock market and it is then reclassified as listed or unlisted 26

Following standard selection criteria used in the literature, observations with negative sales and assets are dropped. Moreover, the dataset only includes firms with unconsolidated accounts to avoid double counting (Greenaway et al., 2007). This also ensures that the sample includes a large number of SMEs. In fact, approximately $60 \%$ of the firms which are included in the dataset are SMEs.

To control for the potential influence of outliers, observations in the one percent tail for each of the regression variables are also excluded. In addition, firms with less than 3years of consecutive observations are also dropped from the sample ${ }^{27}$ By allowing for entry and exit of firms the use of an unbalanced panel partially mitigates potential selection and survivorship bias. The final panel covers 1,509,104 firm-year observations, corresponding to 192,147 euro area firms operating in the manufacturing sector.

\subsection{Descriptive Statistics}

Table 1 reports the summary statistics of the independent variables. When comparing unlisted and listed firms (column 2 and column 3) we find, for example, that unlisted firms are

\footnotetext{
${ }^{23}$ It should be noted that Ireland does not report information for public firms. Also Netherlands does not have enough information on listed/unlisted firms. As a result these countries are dropped from the database.

${ }^{24}$ We do not incude any non-Eurozone countries in our analysis so as to eliminate the impact from currency changes.

${ }^{25}$ It should be noted however, that Amadeus database only provides a contemporaneous information rather than a historical information.

${ }^{26}$ For example, if a firm had an IPO in 2009 and it also has accounting information from 2003 to 2011, Amadeus database classifies the firm as public throughout the sample period. Thus, in this situation the firm is reclassified as unlisted from 2003 to 2008 and as listed from 2009 to 2011 . The same methodology is employed for the delisting case.

${ }^{27}$ See Tables A2 and A3 for the structure of the panel in the appendix.
} 
on average highly leveraged and younger with higher capital expenditures and net working capital, when comparing with their listed counterparts. Figure 2 describes the average cash holdings for unlisted and listed firms. Overall, unlisted firms hold more cash than their listed counterparts, especially during the crisis period. Our findings suggest that unlisted firms where forced to use their reserves during the global and sovereign debt crisis and by 2012 their cash levels decreased significantly. The sudden increase in 2015 may be consistent with the implementation of public financial solutions adopted by euro area countries from 2012 to 2014. According to a recent report by the European Comission (2017) unlisted firms, especially SMEs, received public funding of different forms ${ }^{28}$

\section{Econometric results}

\subsection{Unlisted firms' cash holdings}

Table 2 shows the results from the estimation of equation (1) using a system GMM approach. The results indicate that unlisted firms hold on average more cash compared to listed firms. In particular, unlisted firms hold approximately $67.2 \%$ more cash on average than their listed counterparts. This is consistent with the precautionary motive. Unlisted firms have a higher need to hold more cash than their listed counterparts to counter the impact of financial frictions. The former suffer from higher levels of information asymmetry than the latter and as a result they hoard more cash. This finding contradicts the previous literature which shows that listed firms hold more cash than their unlisted counterparts due to agency motives (Gao et al., 2013).

The remaining control variables have the expected signs. For instance, capital expenditure and leverage have a negative and significant effect, whereas cash flow, sales growth and

${ }^{28}$ According to the European Comission (EU), in 2012 Italy introduced fiscal incentives for the issuing of minibonds by unlisted firms. Similarly, Spain created an Alternative Fixed-Income Market ("Mercado Alternativo de Renta Fija-MARF) which was focused on trading bond of SMEs. Finally, Portugal simplified its legislative framework, making it easier to issue commercial paper for SMEs. 
cash flow volatility exhibit a positive relation with cash. The negative sign on net working capital indicates that it is a substitute for cash. These findings are in line with previous empirical literature. In effect, Gao et al. (2013) note these effects using panels of U.S. and European firms. The diagnostic tests demonstrate that neither the Sargan test (J statistic) nor the $m 3$ test indicate any problems with the choice of instruments or the general specification of the model.

\subsection{The role of financial pressure on cash decisions}

Table 3 estimates again equation (1) using the financial pressure decomposition to lowmiddle-high as discussed earlier. The results show that unlisted firms hold higher levels of cash than their listed counterparts independently of their level of financial pressure. More importantly, results also demonstrate a "U-shaped" relationship between the differential in cash holdings of listed and unlisted firms depending on the level of financial pressure. The relative difference decreases for an average level of financial pressure. In addition, the difference is more pronounced at the lower level of financial pressure compared to the highest level. This is a novel and significant result which extends the argument of Acharya et al. (2012).

At a lower level of financial pressure (column 1), the cash holdings' differential is also higher due to a pecking order issue. Unlisted firms continue to hold higher cash reserves since they suffer from higher levels of financial frictions and prefer to obtain capital from internal funds first than through external capital markets (Acharya et al., 2012). However, at higher levels of financial pressure (column 3), the difference in cash holdings decreases, since all type of firms have a limited access to external finance. However, the unlisted firms prefer to hold more cash compared to listed firms as a precaution against possible cash flow shortfall in the future. 


\subsection{Cash flow sensitivity of cash}

Table 4 shows the results from the estimation of equation (2) following Almeida et al. (2004). In this sub-section we want to assess the cash flow sensitivity of cash. The results indicate that unlisted firms still hold more cash on average compared to the listed firms, at about 70.2\%. More importantly, the results provide evidence that both unlisted and listed firms save cash out of cash flows. The positive and statistically significant coefficient on the interaction term suggest that unlisted firms have a higher cash flow sensitivity of cash than their listed counterparts. This result is a new result which contradicts the recent studies on U.S. and European private and public firms that find a negative coefficient (Farre-Mensa, 2014). Nevertheless, this finding is in line with the argument of Almeida et al. (2004) since cash flow sensitivity of cash is positive for financially constrained firms. These firms have higher levels of information asymmetry. Hence, the empirical finding in Table 4 suggest that unlisted firms can be considered as financially constrained firms.

\subsection{The role of crisis}

What is the effect of the recent financial crisis on the cash holdings behavior? In this section, we examine how crisis affects cash holdings and cash sensitivity of the firms in our sample. To that end we estimate the baseline cash model, equation (1), by adding a crisis dummy which takes the value of one for the period 2007-2009 and zero otherwise.

$$
\begin{aligned}
\text { cash }_{i t}= & \alpha+\beta_{1} \text { Unlisted }_{t}+\beta_{2} \text { Crisis }_{t}+\beta_{3} \text { Unlisted }_{t} \times \text { Crisis }_{t}+\beta_{4} \text { Size }_{i t} \\
& +\beta_{5} \text { CashFlow }_{i t}+\beta_{6} \text { Salesgr }_{i t}+\beta_{7} \text { Lever }_{i t}+\beta_{8} \text { NWC }_{i t}+\beta_{9} \text { CapExp }_{i t} \\
& +\beta_{10} \text { CasfFlow_vol }_{i t}+\beta_{11} \text { Ln }(\text { age })_{i t}+\beta_{12} \text { Cost of empl }_{i t} \\
& +\beta_{13} \text { Sharehold.Funds }_{i t}+\varepsilon_{i t}
\end{aligned}
$$

Our results in Table 5 indicate that during the crisis the demand of cash reserves is still positive and significantly higher for unlisted firms, at about $\mathbf{5 8 . 8 \%}$, supporting the precau- 
tionary theory. This result contradicts the findings of Duchin et al. (2010) that corporate investment declines and cash balance increases during the crisis and that the investment fall is greatest among financially constrained firms and firms with low cash reserves.

Similar pattern is observed for the cash flow sensitivity for cash of unlisted firms compared to the listed counterparts when we modify equation (2) to the following equation:

$$
\begin{aligned}
\Delta \text { cash }_{i t}= & \alpha+\beta_{1} \text { Unlisted }_{t}+\beta_{2} \text { Crisis }_{t}+\beta_{3} \text { Unlisted }_{t} \times \text { Crisis }_{t} \\
& +\beta_{4} \text { Unlisted }_{t} \times \text { CasFlow }_{i t} \times \text { Crisis }_{t}+\beta_{5} \text { Size }_{i t}+\beta_{6} \text { CasFlow }_{i t} \\
& +\beta_{7} \text { Salesgr }_{i t}+\beta_{8} \Delta N W C_{i t}+\beta_{9} \text { CapExp }_{i t}+\beta_{10} \Delta \text { STdebt }_{i t} \\
& +\beta_{11} \text { Cost of empl }_{i t}+\beta_{12} \text { Sharehold.Funds }_{i t}+\varepsilon_{i t}
\end{aligned}
$$

As it is illustrated in Table 6, during the crisis, the coefficient of the interaction term including the effect of crisis for the unlisted firms remains positive and statistical significance. This finding supports the argument of Almeida et al. (2004) and Duchin et al. (2010) that cash flow sensitivity of cash is positive for financially constrained firms.

\section{Robustness checks}

\subsection{Dynamic models}

This sub-section considers the introduction of a lag of the dependent variable Cash $_{i t}$ since firms do not adjust instantaneously to their target cash levels. Table 7 shows the results from re-estimating equation (1) with the inclusion of the lagged cash. The results confirm that unlisted firms continue to hold more cash than their listed counterparts and all the remaining control variables have the expected sign and significance.

Table 8 shows the results from the estimation of the effect of the financial pressure with the inclusion of the lagged cash variable. We find that the "U-shape" effect between cash holdings and financial pressure continues to hold with a positive and statistically significant 
coefficient for cash holdings. Finally, Table 9 shows that cash flow sensitivity of cash is still higher for unlisted firms than listed ones even with the estimation of a dynamic version of the model presented in equation (2).

\subsection{Alternative measure of financial pressure}

This sub-section provides an alternative measure of financial pressure, the debt-capital ratio as defined by Nickell and Nicolitsas (1999). The debt-capital ratio is used two or three years lagged with the contemporaneous change in the 10-year government bond yield. This ensures that the results are not driven by exogenous shifts in the interest rates which can been influenced by government policies. Table 10 shows that the key findings remain unchanged. Unlisted firms hold more cash than their listed counterparts and there is a "U-shaped" relationship between the differential in cash holdings of unlisted and listed firms.

\subsection{Firms' size: Alternative cut-off point}

Here we split the sample of firms according to their size so as to ensure that the results are driven by the large share of small firms in the sample. A 75th percentile is used as a cut-off point to distinguish between large and small firms. In fact, large firms are classified as those whose total assets are above the 75th percentile of the distribution of the assets of all the firms in a particular country, year and industry, and 0 otherwise. Equation (1) is re-estimated only for firms above the 75 th percentile.

Table 11 provides evidence that only large unlisted firms hold less cash than their listed counterparts. This indicates that for large unlisted firms the agency motive is more pronounced than the precautionary one. More importantly, the negative and statistically significant coefficient on the unlisted dummy variable implies that all the previous results are driven by the firms with small size used in our study 29

\footnotetext{
${ }^{29}$ We have also examined classifying firms regarding their level of total assets at a different percentile (i.e. 80 th, 60 th percentile etc.). We do not show the results here to save space, however, we would like to mention that the coefficient of the unlisted dummy becomes positive again at the 66th percentile.
} 


\subsection{Matching sample of unlisted and listed firms}

As a final robustness check, we employ a matching sample procedure to support the power of our empirical results in favor of unlisted firms' cash holdings behavior. The matching procedure controls for the selection of firms based on the observable firm characteristics. In order to make the sample of unlisted and listed firms more comparable in size we implement propensity score-matching based on country, industry and total assets. In particular, we use a one-to-one matching for industry and country and we then use the nearest neighbor matching for total assets utilizing the analytical standard errors as in Abadie and Imbens (2006) ${ }^{30}$

Table 12 shows the results from the estimation of equation (1) using the matched sample ${ }^{31}$ The main results of our analysis remain consistent. The differential cash holdings behavior between unlisted and listed firms still holds and unlisted firms hoard more cash than listed counterparts, at about $66.4 \%$.

\section{Conclusion}

Prior research has shown that unlisted firms hold less cash than their listed counterparts due to agency motives (Gao et al., 2013; Asker et al., 2012). However, this stream of literature is focused mainly on large firms despite the importance of small firms in the worldwide economy. As a result, there is no evidence on how SMEs behave with respect to their cash holdings. Our study shed further light on this issue by exploring the differences in cash reserves of listed and unlisted firms using a large panel of euro area firms, from which there is a large share of SMEs.

Contrary to previous studies, we found that unlisted firms, that are likely to face a

\footnotetext{
${ }^{30}$ We need to use the nearest neighbor matching approach for total assets for a given country and industry because it is impossible to find a listed and an unlisted firm with the exact same level of assets for a given country and industry.

${ }^{31}$ For simplicity we present only the result from the baseline estimation. However, the results of the other estimations remain valid and are availiable upon request.
} 
higher degree of information asymmetries due to their high dependence on external finance, they hold more cash as a precaution. Therefore, our empirical estimates indicated that cash reserves are higher for unlisted firms if a large sample of SMEs is incorporated to the analysis. This result contributes to the trade-off discussion between agency costs and precautionary regarding cash holdings behavior between listed and unlisted firms (Brau and Fawcett, 2006, Gao et al., 2013).

Furthermore, we found that the difference between listed and unlisted firms cash reserves is of a "U-shape" decreasing for an average level of financial pressure and increasing for a high or low level of financial pressure, similarly to Acharya et al. (2012). As it has been shown in Acharya et al. (2012), at the one end of the U-shaped relationship riskier firms hold higher levels of cash as a precaution due to their high levels of debt relative to their cash flows, while at the other end low-risk firms hold again more cash due to pecking order issue. However, our results extended the work of Acharya et al. (2012), who used a sample of public U.S. firms, to a large sample of European firms incorporating listed and unlisted firms with a large share of SMEs. We also assessed the effect of the recent financial crisis on cash holdings behavior between listed and unlisted firms. We found that during the crisis unlisted firms increased their cash reserves more compared to the listed ones.

Our empirical findings complement the related literature on cash holding policies where public/listed firms were mainly examined. In addition, our findings have important policy implications both for the society and corporations. Understanding the mechanisms by which imperfect capital markets affect firms' cash behavior should be a top priority for the Euro-area authorities and their regulations. This is of particular importance for small and constrained firms which are more affected by volatile macroeconomic conditions. Therefore, better informed policy makers may help firms to avoid shortages of credit, loss of profitable investment opportunity sets and preserve jobs. 


\section{References}

Abadie, A. and G. Imbens (2006), 'Large sample properties of matching estimators for average treatment effects', Econometrica 74(1), 235-267.

Acharya, V., S. A. Davydenko and I. A. Strebulaev (2012), 'Cash holdings and credit risk', Review of Financial Studies 25, 3572-3609.

Almeida, H., I. Cunha, M. A. Ferreira and F. Restrepo (2017), 'The real effects of credit ratings: The sovereign ceiling channel', The Journal of Finance 72, 249-290.

Almeida, H., M. Campello and S. Weisbach (2004), 'The cash flow sensitivity of cash', The Journal of Finance 59, 1777-1804.

Arellano, M. and O. Bover (1995), 'Another look at the instrumental variable estimation of error-components models', Journal of Econometrics 68, 29-51.

Asimakopoulos, P., S. Asimakopoulos, N. Kourogenis and E. Tsiritakis (2017), 'Timedisaggregated dividend-price ratio and dividend growth predictability in large equity markets', Journal of Financial and Quantitative Analysis 52, 2305-2326.

Asker, J. W., J. Farre-Mensa and A. Ljungqvist (2012), 'Comparing the investment behavior of public and private firms', NBER Working paper 17394 .

Bates, T. W., K. Kahle and R. Stulz (2009), 'Why do U.S. firms hold so much cash than they used to?', The Journal of Finance 64, 1985-2021.

Baumol, W. J. (1952), 'The transactions demand for cash: An inventory theoretic approach', The Quarterly Journal of Economics 66, 545-556.

Belghitar, Y. and J. Khan (2013), 'Governance mechanisms, investment opportunity holdingsSMEs cash holdings', Small Business Economics 40, 59-72. 
Benito, A. and G. Young (2007), 'Financial pressure and balance sheet adjustment by firms', Oxford Bulletin of Economics and Statistics 69, 581-602.

Bigelli, M. and J. Sánchez-Vidal (2012), 'Cash holdings in private firms', Journal of Banking E Finance 36, 26-35.

Blundell, R. and S. Bond (1998), 'Initial conditions and moment restriction in dynamic panel data models', Journal of Econometrics 87, 115-143.

Blundell, R., S. Bond and F. Windmeijer (2001), 'Estimation in dynamic panel data models: Improving on the performance of the standard GMM estimator', Nonstationary Panels, Panel Cointegration, and Dynamic Panels 15, 53-91.

Brau, J. and S. Fawcett (2006), 'Initial public offerings: An analysis of theory and practice', The Journal of Finance 61, 399-436.

Brav, O. (2009), 'Access to capital, capital structure, and the funding of the firm', The Journal of Finance 64, 263-308.

Brown, J. and B. C. Petersen (2011), 'Cash holdings and R\&D smoothing', Journal of Corporate Finance 17, 694-709.

Brown, R. J., S. M. Fazzari. and B. C. Petersen (2009), 'Financing innovation and growth: Cash flow, external equity, and the 1990s R\&D boom', The Journal of Finance 64, 151185.

Carvalho, D., M. Ferreira and P. Matos (2015), 'Lending relationships and the effect of bank distress: Evidence from the 2007-2008 financial crisis', Journal of Financial and Quantitative Analysis 50, 1165-1197.

Chava, S. and A. Purnanandam (2011), 'The effect of banking crisis on bank-dependent borrowers', Journal of Financial Economics 99, 116-135. 
Chen, M. and A. Guariglia (2013), 'Internal financial constraints and firm productivity in China: Do liquidity and export behavior make a difference?', Journal of Comparative Economics 41, 1123-1140.

Chen, Q., I. Goldstein and W. Jiang (2007), 'Price informativeness and investment sensitivity to stock price', Review of Financial Studies 20, 619-650.

Chen, Q., X. Chen, K. Schipper, Y. Xu and J. Xue (2012), 'The sensitivity of corporate cash holdings to corporate governance', Review of Financial Studies 25, 3610-3644.

de Haan, L. and J. Hinloopen (2003), 'reference hierarchies for internal finance, bank loans, bond, and share issues: Evidence for dutch firms', Journal of Empirical Finance 10, 661681.

De Maeseneire, W. and T. Claeys (2012), 'SMEs, foreign direct investment and financial constraints: The case of Belgium', International Business Review 21, 408-424.

Denis, D. J. (2011), 'Financial flexibility and corporate liquidity', Journal of Corporate Finance 17, 667-674.

Dittmar, A. and J. Mahrt-Smith (2007), 'Corporate governance and the value of cash holdings', Journal of Financial Economics 83, 599-634.

Dittmar, A., J. Mahrt-Smith and H. Servaes (2003), 'International corporate governance and corporate cash holdings', Journal of Financial and Quantitative Analysis 38, 111-133.

Duchin, R., O. Ozbas and A. B. Sensoy (2010), 'Costly external finance, corporate investment, and the subprime mortgage financial crisis', Journal of Financial Economics 97, 418-435.

Edmans, A., I. Goldstein and W. Jiang (2012), 'The real effects of financial markets: The impact of prices on takeovers', The Journal of Finance 67, 933-971. 
European Comission (2017), 'Coping with the international financial crisis at the national level in a european context', Impact and financial sector policy responses in 2008-2015, Banking and Finance .

Farre-Mensa, J. (2014), 'The benefits of selective disclosure:Evidence from Private firms', Harvard Business School working paper .

Ferrando, A. and K. Mulier (2013), 'Do firms use trade credit channel to manage growth?', Journal of Banking \&3 Finance 37, 3035-3046.

Ferreira, M. A. and A. S. Vilela (2004), 'Why do firms hold cash? Evidence from EMU countries', European Finance Management 10, 295-319.

Gao, H., J. Harford. and K. Li (2013), 'Determinants of corporate cash policy: Insights from private firms', Journal of Financial Economics 109, 623-639.

Greenaway, D., A. Guariglia and A. Kneller (2007), 'Financial factors and exporting decisions', Journal of International Economics 73, 377-395.

Gryglewicz, S., L. Mancini, E. Morellec, E. Schroth and P. Valta (2017), 'Transitory versus permanent shocks: Explaining corporate savings and investment', Swiss Finance Institute Reserch Paper 18-21.

Guariglia, A., E. Spaliara and S. Tsoukas (2015), 'To what extent does the interest burden affect firm survival? Evidence from a panel of UK firms during the recent financial crisis', Oxford Bulletin of Economics and Statistics (in press).

Guariglia, A. and J. Yang (2016a), 'Adjustment behavior of corporate cash holdings: the china experience', The European Journal of Finance pp. 1-29.

Guariglia, A. and J. Yang (2016b), 'A balancing act: Managing financial constraints and agency costs to minimize investment inefficiency in the chinese market', Journal of Corporate Finance 36, 111-130. 
Guney, Y., A. Karpuz and N. Ozkan (2017), 'R\&d investments and credit lines', Journal of Corporate Finance 46, 261-283.

Han, S. and J. Qiu (2007), 'Corporate precautionary cash holdings', Journal of Corporate Finance 13, 43-57.

Harford, J. (1999), 'Corporate cash reserves and acquisitions', The Journal of Finance 54, 1969-1997.

Harford, J., S. A. Mansi and W. F. Maxwell (2008), 'Corporate governance and firm cash holdings in the U.S.', Journal of Financial Economics 87, 535-555.

Iskandar-Datta, M. E. and Y. Jia (2012), 'Cross-country analysis of secular cash trends', Journal of Banking and Finance 36, 898-912.

Jensen, M. (1986), 'The agency costs of free cash flow, corporate finance and takeovers', American Economic Review 76, 323-329.

Kalcheva, I. and K. V. Lins (2007), 'International evidence on cash holdings and expected managerial agency problems', Review of Financial Studies 20, 1087-1112.

Keynes, J. M. (1936), The general theory of employment, interest and money, Harcourt Brace.

Kim, C., D. C. Mauer and A. E. Sherman (1998), 'The determinants of corporate liquidity: Theory and evidence', Journal of Financial and Quantitative Analysis 33, 305-334.

Mantecon, T. (2008), 'An analysis of the implications of uncertainty and agency problems on the wealth effects to acquirers of private firms', Journal of Banking and Finance 32, 892905.

Miller, M. H. and D. Orr (1966), 'A model of the demand for money by firms', The Quarterly Journal of Economics 80, 413-435. 
Mortal, Sandra and Natalia Reisel (2013), 'Capital allocation by public and private firms', Journal of Financial and Quantitative Analysis 48, 77-103.

Mulier, K., K. Schoors and B. Merlevede (2016), 'Investment-cash flow sensitivity and financial constraints: Evidence from unquoted european smes', Journal of Banking and Finance 73, 182-197.

Muller, P., S. Devnani, J. Julius, D. Gagliardi and C. Marzocchi (2016), 'Annual report on european smes 2015 / 2016: Sme recovery continues', European Commission .

Myers, S. C. (1984), 'The capital structure puzzle', Journal of Finance 31, 923-931.

Myers, S. C. and N. S. Majluf (1984), 'Corporate financing and investment decisions when firms have information that investors do not have', Journal of Financial Economics 13, $187-221$.

Nickell, S. and D. Nicolitsas (1999), 'How does financial pressure affect firms?', European Economic Review 43, 1435-1456.

Opler, T., L. Pinkowitz, R. Stulz and R. Williamson (1999), 'The determinants and implications of cash holdings', Journal of Financial Economics 52, 3-46.

Ozkan, A. and N. Ozkan (2004), 'Corporate cash holdings: An empirical investigation of UK companies', Journal of Banking \&G Finance 28, 2103-2134.

Pinkowitz, L., R. Stulz and R. Williamson (2006), 'Does the contribution of cash holdings and dividends to firm depend on governance? A cross-country analysis.', The Journal of Finance 61, 2725-2751.

Pinkowitz, L. and R. Williamson (2001), 'Bank power and cash holdings: Evidence from Japan', Review of Financial Studies 14, 1059-1082.

Saunders, A. and S. Steffen (2011), 'The costs of being private: Evidence from the loan market', Review of Financial Studies pp. 1-32. 
Vermoesen, V., M. Deloof and E. Laveren (2013), 'Long-term debt maturity and financing constraints of SMEs during the Global Financial Crisis', Small Business Economics 41, 433-448.

Table 1: Summary statistics

\begin{tabular}{|c|c|c|c|c|}
\hline Variables & $\begin{array}{l}\text { All sample } \\
\text { (1) }\end{array}$ & $\begin{array}{l}\text { Unlisted } \\
(2)\end{array}$ & $\begin{array}{l}\text { Listed } \\
\text { (3) }\end{array}$ & $\begin{array}{l}\text { Diff. } \\
\text { (4) }\end{array}$ \\
\hline Cash & $\begin{array}{l}0.120 \\
(0.145)\end{array}$ & $\begin{array}{l}0.128 \\
(0.149)\end{array}$ & $\begin{array}{l}0.113 \\
0.142)\end{array}$ & 0.000 \\
\hline Size & $\begin{array}{l}7.918 \\
(1.174)\end{array}$ & $\begin{array}{l}7.947 \\
(1.178)\end{array}$ & $\begin{array}{l}7.894 \\
(1.171)\end{array}$ & 0.000 \\
\hline Cash flow & $\begin{array}{l}0.173 \\
(0.186)\end{array}$ & $\begin{array}{l}0.181 \\
(0.188)\end{array}$ & $\begin{array}{l}0.166 \\
(0.184)\end{array}$ & 0.000 \\
\hline Cash flow volatility & $\begin{array}{l}0.048 \\
(1.173)\end{array}$ & $\begin{array}{l}0.045 \\
(0.085)\end{array}$ & $\begin{array}{l}0.050 \\
(1.516)\end{array}$ & 0.081 \\
\hline Sales growth & $\begin{array}{l}0.063 \\
(0.381)\end{array}$ & $\begin{array}{l}0.050 \\
(0.357)\end{array}$ & $\begin{array}{l}0.072 \\
(0.397)\end{array}$ & 0.000 \\
\hline Leverage & $\begin{array}{l}0.118 \\
(0.122)\end{array}$ & $\begin{array}{l}0.146 \\
(0.158)\end{array}$ & $\begin{array}{l}0.096 \\
(0.077)\end{array}$ & 0.000 \\
\hline Net working capital & $\begin{array}{l}0.164 \\
(0.239)\end{array}$ & $\begin{array}{l}0.194 \\
(0.244)\end{array}$ & $\begin{array}{l}0.143 \\
(0.234)\end{array}$ & 0.000 \\
\hline Age & $\begin{array}{l}3.206 \\
(0.594)\end{array}$ & $\begin{array}{l}3.128 \\
(0.657)\end{array}$ & $\begin{array}{l}3.257 \\
(0.542)\end{array}$ & 0.000 \\
\hline Capital Expenditures & $\begin{array}{l}0.077 \\
(0.068)\end{array}$ & $\begin{array}{l}0.099 \\
(0.072)\end{array}$ & $\begin{array}{l}0.062 \\
0.060)\end{array}$ & 0.000 \\
\hline Cost of empl. & $\begin{array}{l}0.330 \\
(0.511)\end{array}$ & $\begin{array}{l}0.327 \\
0.295)\end{array}$ & $\begin{array}{c}0.333 \\
(0.622)\end{array}$ & 0.000 \\
\hline Sharehold. Funds & $\begin{array}{l}0.354 \\
(0.256)\end{array}$ & $\begin{array}{l}0.371 \\
(0.250)\end{array}$ & $\begin{array}{l}0.341 \\
(0.260)\end{array}$ & 0.000 \\
\hline
\end{tabular}

Table 1 reports sample means with standard deviations in parentheses for the explanatory variables. Listed and unlisted refer to firms. Diff. column shows the p-value of the test statistic for the equality of means between listed and unlisted firms. 
Table 2: Cash holdings of unlisted and listed firms

\begin{tabular}{lc} 
& Baseline \\
\hline Unlisted & $0.672^{* *}$ \\
Size & $(2.15)$ \\
& -0.010 \\
Cash flow & $(-0.67)$ \\
& $0.118^{* * *}$ \\
Sales growth & $(3.36)$ \\
& $0.068^{* * *}$ \\
leverage & $(3.13)$ \\
& $-0.114^{* * *}$ \\
Net working capital & $(-2.77)$ \\
& $-0.399^{* * *}$ \\
Capital expenditures & $(-18.04)$ \\
& $-0.334^{* * *}$ \\
Cash flow volatility & $(-3.01)$ \\
& $0.492^{* *}$ \\
ln(Age) & $(2.46)$ \\
& -0.001 \\
Cost of employees & $(-0.12)$ \\
& $0.140^{* * *}$ \\
Shareholder's funds & $(2.65)$ \\
& $0.603^{* * *}$ \\
Observations & $(8.67)$ \\
Number of id & 573,558 \\
m3 (p-value) & 132,095 \\
Hansen J-test (p-value) & 0.122 \\
\hline
\end{tabular}

All specifications are estimated using a system GMM estimator. The figures in parentheses report t-statistics that are asymptotically robust to heteroskedasticity. Country, industry and time dummies are included. Instruments include all regressors lagged three times or more. Hansen J-test is a test of over-identifying restrictions, distributed as chi-square under the null of instrument validity. $\mathrm{m} 3$ is a test for third order serial correlation in the first-differenced residuals, asymptotically distributed as $\mathrm{N}(0,1)$ under the null of no serial correlation. * **, and *** indicate statistical significance at the $10 \%, 5 \%$, and $1 \%$ level, respectively. 
Table 3: The effect of financial pressure

\begin{tabular}{|c|c|c|c|}
\hline & \multicolumn{3}{|c|}{ Financial Pressure } \\
\hline & $\begin{array}{l}\text { Low } \\
(1)\end{array}$ & $\begin{array}{l}\text { Medium } \\
\text { (2) }\end{array}$ & $\begin{array}{l}\text { High } \\
(3)\end{array}$ \\
\hline Unlisted & $\begin{array}{l}0.966^{* * *} \\
(2.24)\end{array}$ & $\begin{array}{l}0.526^{* *} \\
(1.94)\end{array}$ & $\begin{array}{l}0.612^{* * *} \\
(2.41)\end{array}$ \\
\hline Size & $\begin{array}{l}0.017 \\
(0.70)\end{array}$ & $\begin{array}{l}-0.032^{* *} \\
(-2.34)\end{array}$ & $\begin{array}{l}-0.022^{* *} \\
(-2.56)\end{array}$ \\
\hline Cash flow & $\begin{array}{l}0.272^{* * *} \\
(4.76)\end{array}$ & $\begin{array}{l}0.140^{*} \\
(1.85)\end{array}$ & $\begin{array}{l}0.033 \\
(1.34)\end{array}$ \\
\hline Sales growth & $\begin{array}{l}0.014 * * * \\
(5.03)\end{array}$ & $\begin{array}{l}0.003 \\
(0.41)\end{array}$ & $\begin{array}{l}0.007 \\
(0.96)\end{array}$ \\
\hline leverage & $\begin{array}{c}-0.016 \\
(-0.75)\end{array}$ & $\begin{array}{l}-0.080 \\
(-0.87)\end{array}$ & $\begin{array}{l}0.147 \\
(1.62)\end{array}$ \\
\hline Net working capital & $\begin{array}{l}-0.809^{* * *} \\
(-27.05)\end{array}$ & $\begin{array}{l}-0.331 * * * \\
(-3.30)\end{array}$ & $\begin{array}{l}-0.197^{* *} \\
(-2.08)\end{array}$ \\
\hline Capital expenditures & $-0.302^{* * *}$ & 0.231 & 0.024 \\
\hline Cash flow volatility & $\begin{array}{l}0.141 \\
(1.60)\end{array}$ & $\begin{array}{l}0.204 \\
(1.50)\end{array}$ & $\begin{array}{c}-0.052 \\
(-0.58)\end{array}$ \\
\hline $\ln ($ Age $)$ & $\begin{array}{l}-0.042^{* * *} \\
(-4.39)\end{array}$ & $\begin{array}{l}0.013 \\
(1.43)\end{array}$ & $\begin{array}{l}0.008 \\
(1.43)\end{array}$ \\
\hline Cost of Empl. & $\begin{array}{l}0.109 \\
(1.42)\end{array}$ & $\begin{array}{l}-0.114 \\
(-1.51)\end{array}$ & $\begin{array}{c}-0.210^{*} \\
(-1.85)\end{array}$ \\
\hline Sharehold. Funds & $\begin{array}{l}1.077^{* * *} \\
(21.73)\end{array}$ & $\begin{array}{l}0.400^{* * * *} \\
(5.44)\end{array}$ & $\begin{array}{l}0.179^{*} \\
(1.82)\end{array}$ \\
\hline Observations & 48,740 & 58,021 & 58,776 \\
\hline Number of id & 24,537 & 36,079 & 23,291 \\
\hline m3 (p-value) & 0.133 & 0.153 & 0.332 \\
\hline Hansen J-test (p-value) & 0.265 & 0.118 & 0.291 \\
\hline
\end{tabular}

All specifications are estimated using a system GMM estimator. Numbers in parentheses report t-statistics robust to heteroskedasticity. Financial pressure is defined as the coverage ratio. Firms are split accordinging to each decile. Low financial pressure (10th decile), medium financial pressure (5th decile) and higher financial pressure (1st decile). Country, industry and time dummies are included. Instruments include all regressors lagged three times or more. Hansen J-test is a test of over-identifying restrictions. $\mathrm{m} 3$ is a test for third order serial correlation. ${ }^{*},{ }^{* *}$, and ${ }^{* * *}$ indicate statistical significance at the $10 \%, 5 \%$, and $1 \%$ level, respectively. 
Table 4: Cash flow sensitivity of cash

\begin{tabular}{lc} 
& Baseline \\
\hline Unlisted & $0.639^{* *}$ \\
& $(2.03)$ \\
Unlisted * Cash flow & $0.702^{* * *}$ \\
& $(7.85)$ \\
Size & -0.359 \\
& $(-1.89)$ \\
Cash flow & $0.060^{* * *}$ \\
& $(2.74)$ \\
Sales growth & $0.111^{* * *}$ \\
& $(3.50)$ \\
$\Delta$ Net working capital & -0.083 \\
& $(-1.16)$ \\
Capital expenditures & 0.117 \\
& $(0.78)$ \\
$\Delta$ Short term debt & -0.007 \\
& $(-0.60)$ \\
Cost of empl. & $0.299^{* * *}$ \\
& $(5.14)$ \\
Sharehold. Funds & 0.032 \\
& $(0.19)$ \\
\hline Observations & 473,558 \\
Number of id & 122,095 \\
m3 (p-value) & 0.220 \\
Hansen J-test (p-value) & 0.162 \\
\hline
\end{tabular}

All specifications are estimated using a system GMM estimator. Numbers in parentheses report t-statistics robust to heteroskedasticity. Country, industry and time dummies are included. Instruments include all regressors lagged three times or more. Hansen J-test is a test of over-identifying restrictions. $\mathrm{m} 3$ is a test for third order serial correlation. *, **, and *** indicate statistical significance at the $10 \%, 5 \%$, and $1 \%$ level, respectively.

Table 5: Baseline model: Financial crisis and unlisted firms

\begin{tabular}{lc} 
& Baseline \\
\hline Unlisted & $0.630^{* *}$ \\
Crisis & $(1.97)$ \\
& $-0.597^{*}$ \\
Unlisted*Crisis & $(-1.86)$ \\
& $0.588^{*}$ \\
Size & $(1.89)$ \\
& -0.005 \\
Cash flow & $(-0.33)$ \\
& $0.121^{* * *}$ \\
Sales growth & $(3.44)$ \\
& $0.062^{* * *}$ \\
leverage & $(2.70)$ \\
& -0.087 \\
Net working capital & $(-1.28)$ \\
& $-0.400^{* * *}$ \\
Capital expenditures & $-17.68)$ \\
& $-0.310^{* * *}$ \\
Cash flow volatility & $(-2.84)$ \\
& $0.452^{* *}$ \\
ln(Age) & $(2.16)$ \\
Cost of Empl. & -0.005 \\
& $(-0.38)$ \\
Sharehold. Funds & $0.146^{* * *}$ \\
\hline Observations & $(2.81)$ \\
Number of id & $0.599^{* * *}$ \\
m3 (p-value) & $(8.06)$ \\
Hansen J-test (p-value) & 573,558 \\
\hline
\end{tabular}

All specifications are estimated using a system GMM estimator. Numbers in parentheses report t-statistics robust to heteroskedasticity. Crisis is a dummy variable which assumes the value of 1 for the 2007-2009 period, and 0 otherwise. Country, industry and time dummies are included. Instruments include all regressors lagged three times or more. Hansen J-test is a test of over-identifying restrictions. $\mathrm{m} 3$ is a test for third order serial correlation. ${ }^{*},{ }^{* *}$, and ${ }^{* * *}$ indicate statistical significance at the $10 \%, 5 \%$, and $1 \%$ level, respectively. 
Table 6: Cash flow sensitivity of cash: unlisted and crisis

\begin{tabular}{lc} 
& Baseline \\
\hline Unlisted & $0.016^{* * *}$ \\
& $(3.27)$ \\
Crisis & $-0.094^{* * *}$ \\
& $(-2.86)$ \\
Unlisted ${ }^{*}$ Crisis & $0.051^{* *}$ \\
& $(2.33)$ \\
Unlisted*Cash flow*Crisis & $0.180^{* * *}$ \\
& $(2.96)$ \\
Size & $-0.139^{* *}$ \\
& $(-2.56)$ \\
Cash flow & $0.011^{* *}$ \\
& $(2.14)$ \\
Sales growth & $0.110^{* *}$ \\
& $(2.15)$ \\
$\Delta$ Net working capital & 0.108 \\
Capital expenditures & $(0.58)$ \\
& 0.456 \\
$\Delta$ Short term debt & $(1.32)$ \\
& -0.002 \\
Cost of empl. & $(-0.04)$ \\
& $0.606^{* * *}$ \\
Sharehold. Funds & $(4.07)$ \\
& -0.287 \\
\hline Observations & $(-0.80)$ \\
Number of id & 471,082 \\
m3 (p-value) & 120,012 \\
Hansen J-test (p-value) & 0.213 \\
\hline
\end{tabular}

All specifications are estimated using a system GMM estimator. Numbers in parentheses report t-statistics robust to heteroskedasticity. Country, industry and time dummies are included. Instruments include all regressors lagged three times or more. Hansen J-test is a test of over-identifying restrictions. $\mathrm{m} 3$ is a test for third order serial correlation. *, **, and *** indicate statistical significance at the $10 \%, 5 \%$, and $1 \%$ level, respectively.

Table 7: Cash holdings of unlisted and listed firms: Dynamic panel

\begin{tabular}{lc} 
& Baseline \\
\hline L.cash & $0.992^{* * *}$ \\
Unlisted & $(11.81)$ \\
& $0.855^{* * *}$ \\
Size & $(2.12)$ \\
Cash flow & -0.015 \\
& $(-0.68)$ \\
Sales growth & $0.122^{* *}$ \\
& $(2.37)$ \\
leverage & $0.178^{* * *}$ \\
& $(5.92)$ \\
Net working capital & $-0.113^{*}$ \\
& $(-1.91)$ \\
Capital expenditures & $0.632^{* * *}$ \\
& $(6.43)$ \\
Cash flow volatility & $-0.323^{* *}$ \\
& $(-2.26)$ \\
ln(Age) & $1.002^{* * *}$ \\
& $(3.29)$ \\
Cost of Empl. & 0.024 \\
Sharehold. Funds & $(1.22)$ \\
& 0.038 \\
& $(0.51)$ \\
Observations & $-0.263^{* *}$ \\
Number of id & $(-2.05)$ \\
m3 (p-value) & 570,082 \\
Hansen J-test (p-value) & 131,708 \\
\hline
\end{tabular}

All specifications are estimated using a system GMM estimator. Numbers in parentheses report t-statistics robust to heteroskedasticity. Country, industry and time dummies are included. Instruments include all regressors lagged three times or more. Hansen J-test is a test of over-identifying restrictions. $\mathrm{m} 3$ is a test for third order serial correlation. *, **, and *** indicate statistical significance at the $10 \%, 5 \%$, and $1 \%$ level, respectively. 
Table 8: The effect of financial pressure: Dynamic pane

\begin{tabular}{|c|c|c|c|}
\hline & \multicolumn{3}{|c|}{ Financial Pressure } \\
\hline & $\begin{array}{l}\text { Low } \\
(1)\end{array}$ & $\begin{array}{l}\text { Medium } \\
(2)\end{array}$ & $\begin{array}{c}\text { High } \\
(3)\end{array}$ \\
\hline L.cash & $0.657^{* * *}$ & $0.601^{* * *}$ & $0.852^{* * *}$ \\
\hline Unlisted & $\begin{array}{c}0.539^{* *} \\
(1.95)\end{array}$ & $0.136^{*}$ & $0.390^{* *}$ \\
\hline Size & $\begin{array}{c}-0.047^{* *} \\
(-2.31)\end{array}$ & $\begin{array}{l}0.027 \\
(1.52)\end{array}$ & $\begin{array}{l}0.016 \\
(1.28)\end{array}$ \\
\hline Cash flow & $\begin{array}{c}0.453^{* * *} * \\
(2.71)\end{array}$ & $\begin{array}{l}0.045 \\
(0.88)\end{array}$ & $\begin{array}{l}-0.077 \\
(-1.57)\end{array}$ \\
\hline Sales growth & $\begin{array}{l}-0.001 \\
(-0.03)\end{array}$ & $\begin{array}{l}0.042 \\
(1.17)\end{array}$ & $\begin{array}{c}0.029^{*} \\
(1.68)\end{array}$ \\
\hline leverage & $\begin{array}{l}-0.004 \\
(-0.05)\end{array}$ & $\begin{array}{l}0.031 \\
(0.39)\end{array}$ & $\begin{array}{l}-0.068 \\
(-0.30)\end{array}$ \\
\hline Net working capital & $\begin{array}{l}0.192 \\
(1.01)\end{array}$ & $\begin{array}{c}0.210^{* *} \\
(2.43)\end{array}$ & $\begin{array}{c}0.249^{* * *} * \\
(3.52)\end{array}$ \\
\hline Capital expenditures & $\begin{array}{l}-0.224 \\
(-1.28)\end{array}$ & $\begin{array}{l}-0.145 \\
(-0.64)\end{array}$ & $\begin{array}{l}-0.103 \\
(-0.64)\end{array}$ \\
\hline Cash flow volatility & $\begin{array}{l}0.350 \\
(0.87)\end{array}$ & $\begin{array}{c}0.313^{*} \\
(1.91)\end{array}$ & $\begin{array}{l}0.125 \\
(0.73)\end{array}$ \\
\hline $\ln ($ Age $)$ & $\begin{array}{c}-0.020^{*} \\
(-1.94)\end{array}$ & $\begin{array}{l}-0.017 \\
(-1.27)\end{array}$ & $\begin{array}{l}0.015 \\
(1.57)\end{array}$ \\
\hline Cost of Empl. & $\begin{array}{l}0.037 \\
(0.42)\end{array}$ & $\begin{array}{c}0.192^{* *} \\
(1.96)\end{array}$ & $\begin{array}{l}0.251^{*} \\
(1.71)\end{array}$ \\
\hline Sharehold. Funds & $\begin{array}{c}0.434^{* * *} * \\
(2.72)\end{array}$ & $\begin{array}{l}0.061 \\
(0.59)\end{array}$ & $\begin{array}{c}-0.398^{* *} \\
(-2.00)\end{array}$ \\
\hline Observations & 48,510 & 57,620 & 58,599 \\
\hline Number of id & 24,434 & 35,871 & 23,218 \\
\hline m3 (p-value) & 0.014 & 0.015 & 0.023 \\
\hline Hansen J-test (p-value) & 0.228 & 0.106 & 0.214 \\
\hline
\end{tabular}

All specifications are estimated using a system GMM estimator. Numbers in parentheses report t-statistics robust to heteroskedasticity. Financial pressure is defined as the coverage ratio. Firms are split accordinging to each decile. Low financial pressure (10th decile), medium financial pressure (5th decile) and higher financial pressure (1st decile). Country, industry and time dummies are included. Instruments include all regressors lagged three times or more. Hansen J-test is a test of over-identifying restrictions. $\mathrm{m} 3$ is a test for third order serial correlation. ${ }^{*},{ }^{* *}$, and ${ }^{* * *}$ indicate statistical significance at the $10 \%, 5 \%$, and $1 \%$ level, respectively. 
Table 9: Cash flow sensitivity of cash:Dynamic Panel

\begin{tabular}{lc} 
& Baseline \\
\hline L.cash & $0.794^{* * *}$ \\
& $(30.80)$ \\
Unlisted & $0.020^{* * *}$ \\
& $(3.04)$ \\
Unlisted * Cash flow & $0.022^{* *}$ \\
& $(2.54)$ \\
Size & 0.016 \\
& $(1.01)$ \\
Cash flow & $0.015^{* * *}$ \\
& $(2.58)$ \\
Sales growth & 0.040 \\
& $(1.63)$ \\
$\Delta$ Net working capital & -0.035 \\
& $(-0.64)$ \\
Capital expenditures & -0.092 \\
& $(-0.61)$ \\
$\Delta$ Short term debt & $-0.015^{* * *}$ \\
& $(-2.64)$ \\
Cost of empl. & $0.126^{* * *}$ \\
Sharehold. Funds & $(2.70)$ \\
& 0.184 \\
& $(1.42)$ \\
\hline Observations & 471,082 \\
Number of id & 120,012 \\
m3 (p-value) & 0.887 \\
Hansen J-test (p-value) & 0.297 \\
\hline
\end{tabular}

All specifications are estimated using a system GMM estimator. Numbers in parentheses report t-statistics robust to heteroskedasticity. Country, industry and time dummies are included. Instruments include all regressors lagged three times or more. Hansen J-test is a test of over-identifying restrictions. $\mathrm{m} 3$ is a test for third order serial correlation. *, **, and *** indicate statistical significance at the $10 \%, 5 \%$, and $1 \%$ level, respectively. 
Table 10: The effect of financial pressure: alternative definition of financial pressure

\begin{tabular}{|c|c|c|c|}
\hline & \multicolumn{3}{|c|}{ Financial Pressure } \\
\hline & $\begin{array}{l}\text { Low } \\
(1)\end{array}$ & $\begin{array}{l}\text { Medium } \\
\quad(2)\end{array}$ & $\begin{array}{c}\text { High } \\
(3)\end{array}$ \\
\hline Unlisted & $\begin{array}{c}0.803^{\text {** }} \\
(1.95)\end{array}$ & $\begin{array}{l}0.309^{*} \\
(1.79)\end{array}$ & $\begin{array}{c}0.719^{* *} \\
(1.93)\end{array}$ \\
\hline Size & $\begin{array}{c}-0.036^{*} \\
(-1.68)\end{array}$ & $\begin{array}{l}0.019 \\
(0.45)\end{array}$ & 0.058 \\
\hline Cash flow & $\begin{array}{c}0.056 \\
(0.97)\end{array}$ & $\begin{array}{c}0.151^{* *} \\
(2.04)\end{array}$ & $\begin{array}{c}0.043^{* * *} \\
(3.14)\end{array}$ \\
\hline Sales growth & $\begin{array}{l}0.022 \\
(0.50)\end{array}$ & $\begin{array}{l}0.035 \\
(0.82)\end{array}$ & $\begin{array}{l}0.025 \\
(0.79)\end{array}$ \\
\hline leverage & $\begin{array}{l}-0.129 \\
(-1.11)\end{array}$ & $\begin{array}{c}-0.332^{*} \\
(-1.88)\end{array}$ & $\begin{array}{l}-0.019 \\
(-0.16)\end{array}$ \\
\hline Net working capital & $\begin{array}{l}-0.082 \\
(-1.29)\end{array}$ & $\begin{array}{c}-0.398^{* * *} \\
(-6.99)\end{array}$ & $\begin{array}{c}-0.684 * * * \\
(-21.41)\end{array}$ \\
\hline Capital expenditures & $\begin{array}{l}0.068 \\
(0.22)\end{array}$ & $\begin{array}{l}-0.095 \\
(-0.36)\end{array}$ & $\begin{array}{l}-0.040 \\
(-0.16)\end{array}$ \\
\hline Cash flow volatility & $\begin{array}{l}0.744 \\
(1.53)\end{array}$ & $\begin{array}{l}0.626 \\
(1.31)\end{array}$ & $\begin{array}{c}-1.056 * * * \\
(-3.05)\end{array}$ \\
\hline $\ln ($ Age $)$ & $\begin{array}{l}0.012 \\
(0.91)\end{array}$ & $\begin{array}{l}-0.020 \\
(-0.84)\end{array}$ & $\begin{array}{c}-0.068^{* * *} \\
(-4.20)\end{array}$ \\
\hline Cost of empl. & $\begin{array}{l}-0.165 \\
(-1.22)\end{array}$ & $\begin{array}{l}0.149 \\
(0.83)\end{array}$ & $\begin{array}{c}0.347^{* *} \\
(2.50)\end{array}$ \\
\hline Sharehold. Funds & $\begin{array}{c}0.195^{*} \\
(1.82)\end{array}$ & $\begin{array}{c}0.531^{* * *} * \\
(4.18)\end{array}$ & $\begin{array}{c}0.926^{* * *} \\
(15.69)\end{array}$ \\
\hline Observations & 58,880 & 60,273 & 97,754 \\
\hline Number of id & 22,827 & 31,889 & 44,834 \\
\hline m3 (p-value) & 0.994 & 0.496 & 0.830 \\
\hline Hansen J-test (p-value) & 0.529 & 0.271 & 0.650 \\
\hline
\end{tabular}

All specifications are estimated using a system GMM estimator. Numbers in parentheses report t-statistics robust to heteroskedasticity. Financial pressure is defined as the debt-to-equity ratio. Firms are split accordinging to each decile of the debt-capital ratio. Low financial pressure (1st decile), medium financial pressure (5th decile) and higher financial pressure (10th decile). The debt-to-capital ratio is the product of debt-capital ratio three years lagged and the contemporaneous change in the 10-year bond. Country, industry and time dummies are included. Instruments include all regressors lagged three times or more. Hansen J-test is a test of over-identifying restrictions. $\mathrm{m} 3$ is a test for third order serial correlation. *, **, and *** indicate statistical significance at the $10 \%, 5 \%$, and $1 \%$ level, respectively. 
Table 11: Baseline model for large firms in the sample

\begin{tabular}{lc} 
& Baseline \\
\hline Unlisted & $-0.054^{* *}$ \\
Size & $(-2.20)$ \\
& 0.010 \\
Cash flow & $(1.44)$ \\
& $0.019^{* *}$ \\
Sales growth & $(2.09)$ \\
& $-0.006^{* * *}$ \\
leverage & $(-7.74)$ \\
& $0.055^{* * *}$ \\
Net working capital & $(4.73)$ \\
& $-0.369^{* * *}$ \\
Capital expenditures & $(-26.86)$ \\
& $-0.147^{* * *}$ \\
Cash flow volatility & $(-2.80)$ \\
& 0.006 \\
ln(Age) & $(0.01)$ \\
& 0.012 \\
Cost of empl. & $(1.21)$ \\
& $0.096^{* *}$ \\
Sharehold. Funds & $(2.55)$ \\
& $0.303^{* * *}$ \\
& $(19.83)$ \\
\hline Observations & 146,721 \\
Number of id & 47,589 \\
m3 (p-value) & 0.115 \\
Hansen J-test (p-value) & 0.125 \\
\hline
\end{tabular}

All specifications are estimated using a system GMM estimator. Numbers in parentheses report t-statistics robust to heteroskedasticity. Unlisted firms are those in the upper 25 percentile of firms' size. Country, industry and time dummies are included. Instruments include all regressors lagged three times or more. Hansen J-test is a test of over-identifying restrictions. $\mathrm{m} 3$ is a test for third order serial correlation. *,**, and *** indicate statistical significance at the $10 \%, 5 \%$, and $1 \%$ level, respectively.

Table 12: Cash holdings of unlisted and listed firms: Matching sample

\begin{tabular}{lc} 
& Baseline \\
\hline Unlisted & $0.664^{* *}$ \\
Size & $(2.13)$ \\
& -0.011 \\
Cash flow & $(-0.77)$ \\
& $0.119^{* * *}$ \\
Sales growth & $(3.33)$ \\
& $0.071^{* * *}$ \\
Leverage & $(3.22)$ \\
Net working capital & $-0.136^{* * *}$ \\
& $(-3.26)$ \\
Capital expenditures & $-0.399^{* * *}$ \\
& $-(-17.76)$ \\
Cash flow volatility & $(-2.98 *)$ \\
& $0.505^{* *}$ \\
ln(Age) & $(2.49)$ \\
& -0.001 \\
Cost of empl. & $(-0.07)$ \\
Sharehold. Funds & $0.138^{* * *}$ \\
& $(2.60)$ \\
& $0.610^{* * *}$ \\
Observations & $(8.55)$ \\
Number of id & 573,558 \\
m3 (p-value) & 132,095 \\
Hansen J-test (p-value) & 0.133 \\
& 0.105 \\
\hline
\end{tabular}

All specifications are estimated using a system GMM estimator. Numbers in parentheses report t-statistics robust to heteroskedasticity. Here we match listed to unlisted firms with exact matches on country and industry and the closest possible match on total assets. Country, industry and time dummies are included. Instruments include all regressors lagged three times or more. Hansen J-test is a test of over-identifying restrictions. m3 is a test for third order serial correlation. *, **, and ${ }^{* * *}$ indicate statistical significance at the $10 \%, 5 \%$, and $1 \%$ level, respectively. 


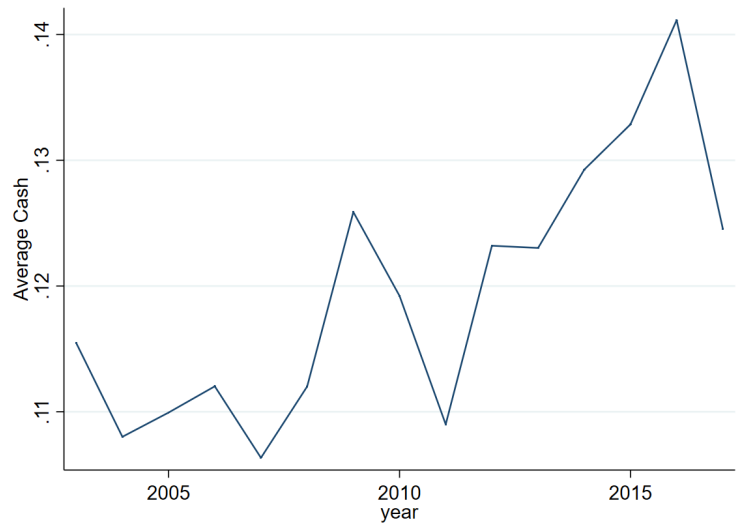

Figure 1: This figure describes the average cash holdings for unlisted and listed firms across euro area during the period 2003-17.

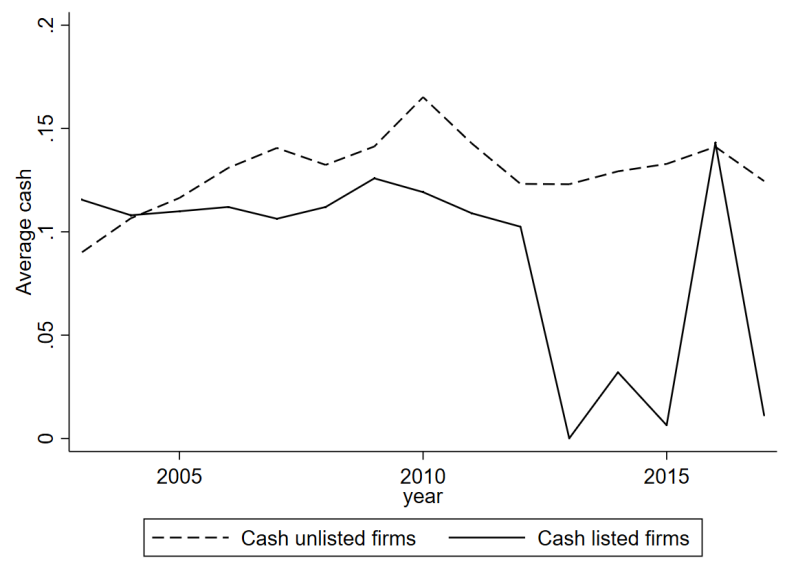

Figure 2: This figure describes the mean cash holdings for listed and unlisted firms for the period 2003-17. 









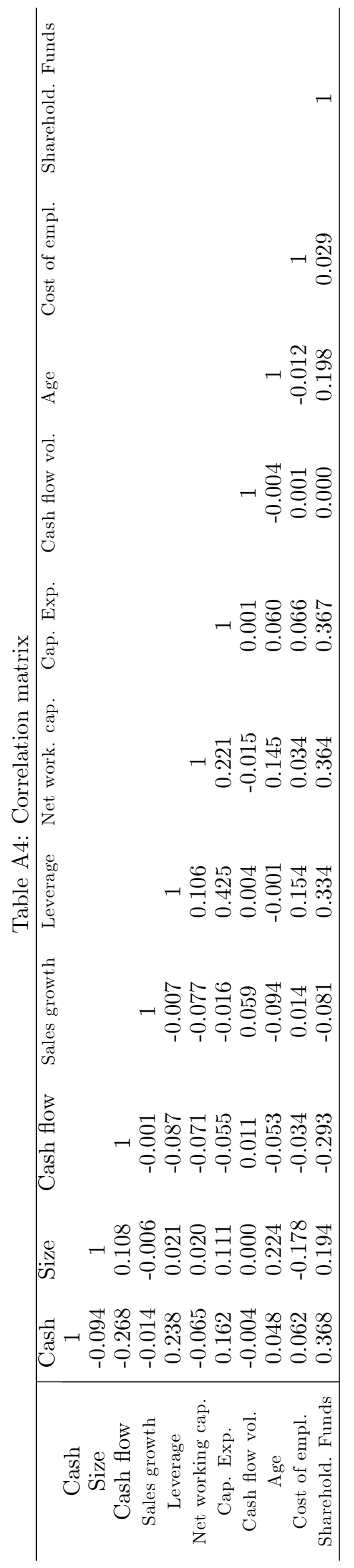

